\title{
Merancang Aplikasi Database Keuangan untuk Pengelolaan Keuangan Pembangkit Listrik Tenaga Mikrohidro (PLTMh)
}

\author{
Irda Rosita1 , Eliyanora ${ }^{2}$, Diyah Hastiyahsari ${ }^{3}$ \\ 1 Jurusan Akuntansi Politeknik Negeri Padang \\ Email: irda.rosita@yahoo.com \\ 2 Jurusan Akuntansi Politeknik Negeri Padang \\ Email: norabuan93@gmail.com \\ 3 Jurusan Akuntansi Politeknik Negeri Padang \\ Email:diyahastiyahs@gmail.com)
}

\begin{abstract}
Abstrak
Pembangkit Listrik Tenaga Mikrohidro (PLTMh) dapat menjadi solusi alternatif pemerataan aliran listrik di berbagai daerah yang tidak terjangkau oleh PLN. PLTMh umumnya dikelola secara swadaya oleh masyarakat yang berada disekitar PLTMh tersebut. Akan tetapi, jika PLTMh yang tidak dikelola dengan baik, akan mengakibatkan PLTMh tidak berfungsi karena ketiadaan pendanaan untuk menutupi biaya operasional PLTMh, terutama biaya pemeliharaan turbin. Oleh karena itu, pengurus PLTMh perlu diberikan pelatihan tentang pengelolaan keuangan dan dibuatkan sebuah aplikasi pengelolaan keuangan yang dapat membantu pengurus dalam pelaporan keuangannya.

Pembangkit Listrik Tenaga Mikro Hidro (PLTMH) Korong Wonorejo, Kenagarian Lubuk Gadang, Kecamatan Sangir, Kabupaten Solok Selatan, Sumatera Barat merupakan sebuah PLTMh yang didirikan atas keinginan warga desa Wonorejo untuk memiliki listrik di daerahnya. Saat ini, pengurus PLTMh Wonorejo melakukan pencatatan transaksi secara manual. Hal ini mengakibatkan pengurus PLTMh tidak dapat menyediakan informasi keuangan yang bersifat real time. Setelah dilakukan survey awal untuk melihat pencatatan yang dilakukan, dirancangkanlah sebuah aplikasi databse keuangan dengan menggunakan Microsoft Access 2010. Diharapkan setelah menggunakan aplikasi ini, pengurus dapat menyiapkan pelaporan keuangan dengan lebih cepat dan mudah dan dari segi penyimpanan data menjadi lebih rapi dan efisien.
\end{abstract}

Keyword: PLTMh, aplikasi keuangan, MS.Access 2010

\section{Latar Belakang}

Listrik merupakan sumber energi yang paling banyak digunakan oleh masyarakat pada saat ini. Akan tetapi, masih saja ada daerah yang tidak terjangkau oleh aliran listrik dari PLN. Pembangkit Listrik Tenaga Mikrohidro (PLTMh) merupakan salah satu solusi untuk pemerataan aliran listrik. PLTMh merupakan sumber energi yang ramah lingkungan dan merupakan salah satu sumber energi yang terbarukan.

Dalam pembangunannya, PLTMh dapat didanai melalui program pemerintah dan ada juga yang didanai dari organisasi non pemerintah. Pada umumnya setelah PLTMh dibangun, pengelolaan PLTMh diserahkan kepada masyarakat di sekitar PLTMh. Masyarakat diharapkan secara mandiri dapat mencari sumber pendanaan sendiri untuk membiayai operasional PLTMh. Akan tetapi, banyak PLTMh yang rusak karena tidak dikelola dengan baik (Yunianto, 2011). Salah satu sebabnya adalah karena tidak adanya dana pemeliharaan PLTMh. Ketiadaaan dana ini bisa disebabkan karena pengelolaan keuangan yang tidak baik, dikarenakan pengurus PLTMh tidak memiliki latar belakang keilmuan akuntansi dan keuangan. Pengelolaan keuangan yang dilakukan secara manual, membuat pengurus PLTMh 
tidak dapat menyediakan informasi keuangan secara real time. Oleh karena itu, perlu dirancangkan sebuah aplikasi keuangan yang sesuai untuk PLTMh. Dalam pembuatan aplikasi keuangan ini, disesuaikan dengan kebutuhan pengguna (user) yaitu PLTMh Korong Wonorejo yang telah dipilih sebagai objek dalam pembuatan aplikasi keuangan ini.

\section{PLTMh Korong Wonorejo}

Pembangkit Listrik Tenaga Mikro Hidro (PLTMH) Korong Wonorejo, Kenagarian Lubuk Gadang, Kecamatan Sangir, Kabupaten Solok Selatan, Sumatera Barat merupakan sebuah PLTMh yang didirikan atas keinginan warga desa Wonorejo untuk memiliki listrik di daerahnya. Keinginan warga tersebut akhirnya mendorong Johny Ivan, seorang tokoh masyarakat desa Wonorejo untuk membangun sebuah PLTMh secara mandiri tanpa bantuan pemerintah. PLTMh Wonorejo ini dibangun di aliran sungai Batang Anjungan Kenagarian Lubuk Gadang Kecamatan Sangir Solok Selatan. Pembangunan PLTMH dimulai pada tahun 2005 dan selesai tahun 2007.

Pada awalnya, dalam hal penetapan tarif listrik PLTMh, pengurus mengadakan musyawarah bersama warga Wonorejo. Dari hasil musyawarah tersebut, masyarakat memutuskan untuk menghitung tarif listrik PLTMh berdasarkan banyaknya titik lampu di setiap rumah. Pada umumnya satu rumah minimal harus memiliki 3 tiga titik lampu yang dikenakan tarif Rp 7.500,-- Harga tersebut belum termasuk biaya tambahan untuk alat elektronoik seperti mesin cuci, kulkas, TV serta biaya beban.

Sistem ini bertahan selama 11 (sebelas) tahun dengan memanfaatkan sebuah turbin dari CV Prowater. Turbin tersebut dapat memenuhi kebutuhan listrik untuk 140 rumah dengan batas waktu nyala dan mati sesuai kesepakatan masyarakat. Listrik akan dimatikan pada pukul 07.00 WIB dan dihidupkan kembali pukul 11.30 WIB. Namun, seiring berjalannya waktu semakin banyak warga yang tidak melaporkan tentang penambahan titik lampu atau barang elektronik yang digunakan kepada pengurus. Hal ini menyebabkan kinerja turbin semakin berat dan tidak terkontrol sehingga dapat mengancam keberlangsungan PLTMh. Selain itu juga menimbulkan kecemburuan sosial antar warga karena merasa diperlakukan secara tidak adil. Sampai akhirnya MCAI melalui IIEE menghibahkan sebuah turbin dengan kapasitas yang lebih besar dibandingkan dengan turbin sebelumnya. Dengan adanya 2 (dua) turbin, PLTMh Wonorejo dapat memenuhi kebutuhan listrik untuk lebih dari 180 rumah warga. Saat ini listrik di Wonorejo dapat dinikmati selama 24 jam. Selain itu, dasar perhitungan tarif listrik berubah menjadi kWh dengan menggunakan meteran. Berikut ini adalah rumus tarif yang akan dikenakan kepada pelanggan PLTMH setiap bulannya:

Tarif per Bulan $=$ Rp $500 \times$ Jumlah $\mathrm{kWh}+$ Beban $(\mathrm{Rp}$ 15.000)

Gambar 1 : Rumus Pengenaan Tarif Berdasarkan kWh

Penggunaan sistem penentuan tarif berdasarkan $\mathrm{kWh}$ ini, memudahkan pengurus dalam menghitung jumlah iuran yang harus dibayarkan oleh pelanggan. Namun secara keseluruhan, keadaan masyarakat Wonorejo sekarang ini jauh lebih baik dibandingkan dengan masa sebelum adanya listrik.

\section{Pengelolaan Keuangan pada PLTMh Wonorejo}

Saat ini, pengurus PLTMh Wonorejo melakukan pencatatan transaksi secara manual. Hal ini mengakibatkan pengurus PLTMh tidak dapat menyediakan informasi keuangan yang bersifat real time dan tidak akuntabel. Pengelolaan keuangan PLTMhyang tidak akuntabel akan dapat mengurangi kepercayaan masyarakat sekitar akan kredibiltas pengelolaan PLTMh. JIka ini terus berlanjut, masyarakat akan menjadi enggan dalam membayar iuran 
listrik. PAdahal iuran listrik merupakan sumber dana utama bagi PLTMh untuk menutupi biaya operasional PLTMh, termasuk biaya pemeliharaan turbin. Jika turbin rusak dan tidak berfungsi, masyarakat pengguna jasa PLTMh jualah yang akan terkena dampak langsung.

Memanfaatkan teknologi seperti komputer akan diharapkan dapat mengatasi permsalahan PLTMh dalam pengelolaan keuangannya. Komputer memiliki berbagai fasilitas yang dapat digunakan untuk memudahkan dalam pencatatan transaksi, oleh karena itu penulis mencoba menerapkan aplikasi Microsoft Access 2010 pada PLTMH Wonorejo untuk pencatatan transaksinya. Pencatatan transaksi menggunakan Microsoft Access 2010 pada dasarnya sama dengan pencatatan secara manual, hanya saja dengan menggunakan aplikasi ini akan lebih cepat dan mudah dalam pencatatan transaksi dan dalam segi penyimpanan data lebih rapi dan efisien.

\section{Perancangan Aplikasi Database Keuangan untuk PLTMh}

Sebelum merancang sebuah database, perlu disusun terlebih dahulu struktur database, yang akan menggambarkan seluruh rangkaian modul-modul database, yang saling berkaitan antara satu sama lain. Penyusunan struktur database ini dimaksudkan untuk mempermudah dalam memahami keterkaitan masing-masing modul database yang akan dirancang. Struktur program dapat digambarkan seperti yang terlihat pada Gambar 2 berikut ini :

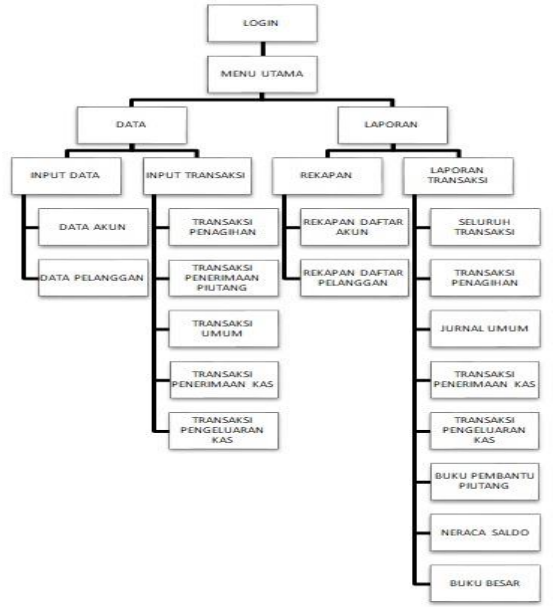

Gambar 2 : Struktur Database Akuntansi

1. Data

Data merupakan langkah awal dalam menjalankan Database ini, dalam modul data terdapat dua bagian, yaitu Input data dan Input transaksi.

a. Input data

Input data digunakan untuk memasukkan data akun seperti kode akun, nama akun, kelompok akun, Input transaksi, kode pelanggan, nama pelanggan dan lain-lain.

b. Input transaksi

Input transaksi digunakan untuk mencatat transaksi-transaksi kedalam jurnal.Transaksi-transaksi yang dicatat kedalam jurnal yaitu transaksi umum,transaksi penagihan, transaksi penerimaan piutang, transaksi penerimaan kas, dan transaksi pengeluaran kas.

2. Laporan 
Laporan merupakan output yang dihasilkan dari pengolahan data serta pencatatan transaksi - transaksi kedalam jurnal.

\section{Application Architecture Design}

Aplikasi sistem informasi administrasi keuangan dibangun dalam arsitektur PHP dan MySQL sebagai database server. Aplikasi ini dapat dijalankan secara lokal maupun dalam jaringan dengan menggunakan software aplikasi web browser.

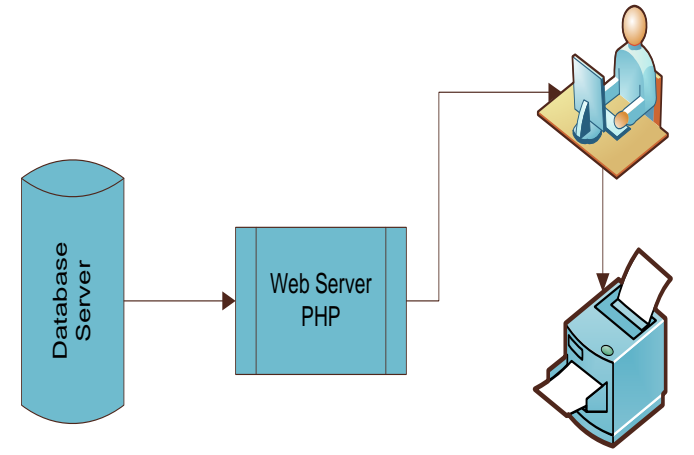

Gambar 3. Application Architecture Design

Untuk dapat menunjang aplikasi sistem informasi ini dapat berjalan dengan baik, maka diperlukan spesifikasi peralatan (hardware) sebagai berikut:

\begin{tabular}{|l|l|}
\hline \multicolumn{1}{|c|}{ Hardware } & \multicolumn{1}{|c|}{ Spesifikasi } \\
\hline Built-up PC & Intel Core i3 4th \\
Generation \\
2GB DDR3 \\
& 500 GB Harddisk \\
& $10 / 100 / 1000 \quad$ Mbps \\
& Ethernet \\
& 650VA Uninteruptible \\
& Power Supply \\
\hline Notebook & Intel Core i3 4th \\
& Generation \\
& 2GB DDR3 \\
& 500 GB Harddisk \\
& $10 / 100 / 1000 \quad$ Mbps \\
& Ethernet \\
& WLAN/Bluetooth \\
\hline Printer & HP Deskjet 1515 \\
& Multifunction Inkjet \\
& Printer \\
\hline
\end{tabular}

\section{Tampilan Aplikasi Keuangan}

Setelah dirancang, tampilan form background dapat dilihat pada Gambar 4 di bawah ini: 


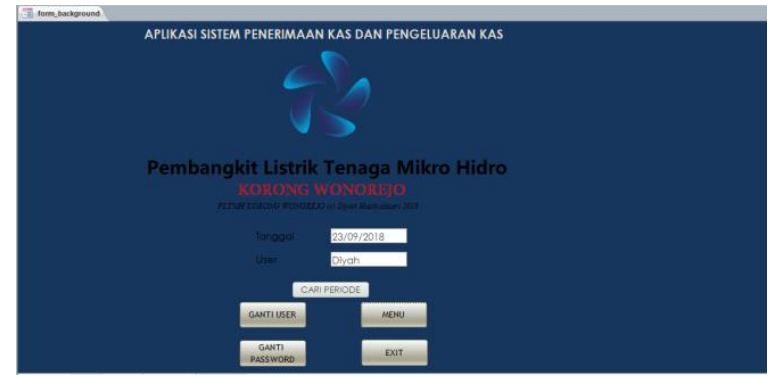

Gambar 4. Tampilan form background

Sedangkan untuk tampilan menu, dapat dilihat pada Gambar 5 berikut:

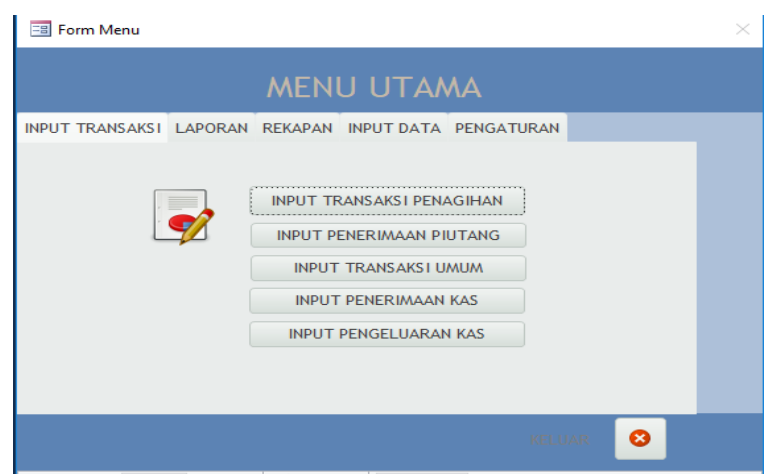

Gambar 5. Tampilan Menu

Tampilan faktur penagihan dapat dilihat pada Gambar 6 berikut:

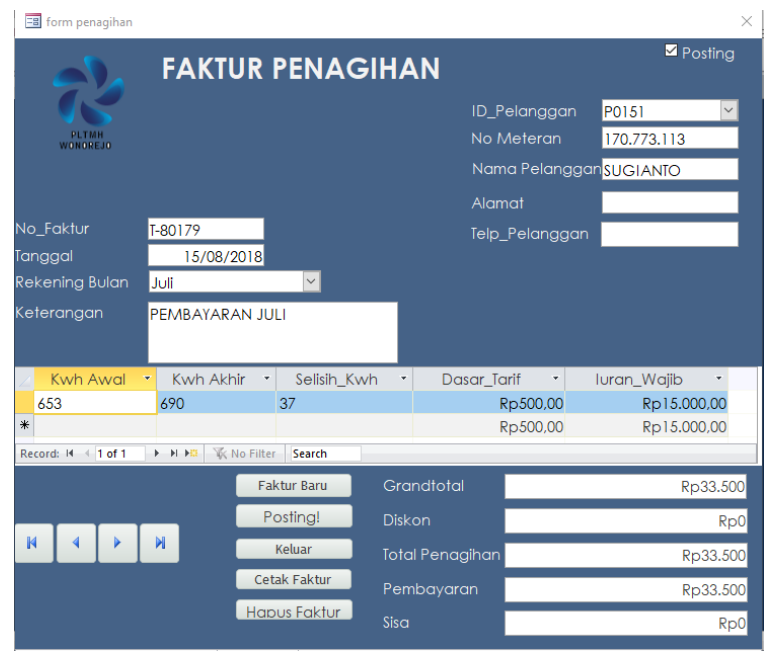

Gambar 6. Faktur Penagihan

Tampilan faktur penerimaan kas seperti terlihat dalam Gambar 7 berikut ini: 


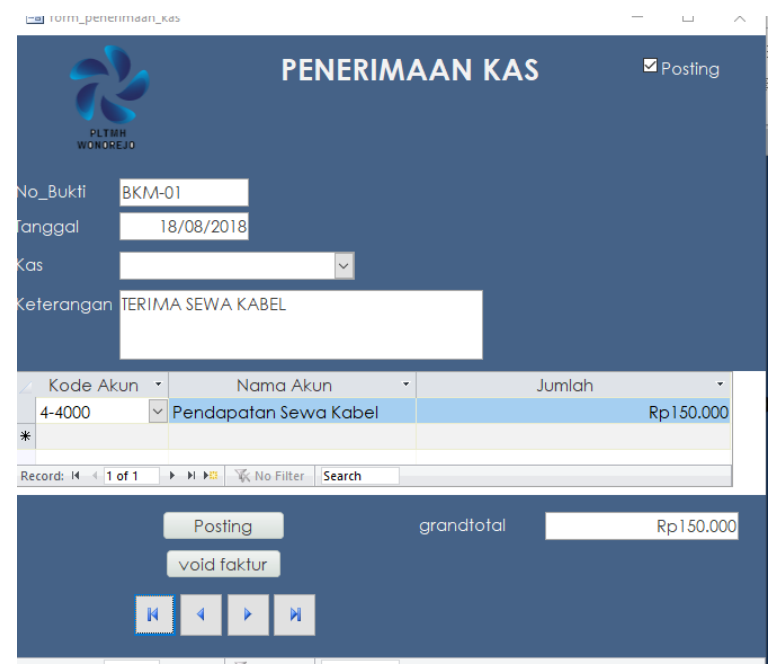

Gambar 7. Faktur Penerimaan Kas

Sedangkan tampilan faktur pengeluaran kas seperi terlihat pada Gambar 8:

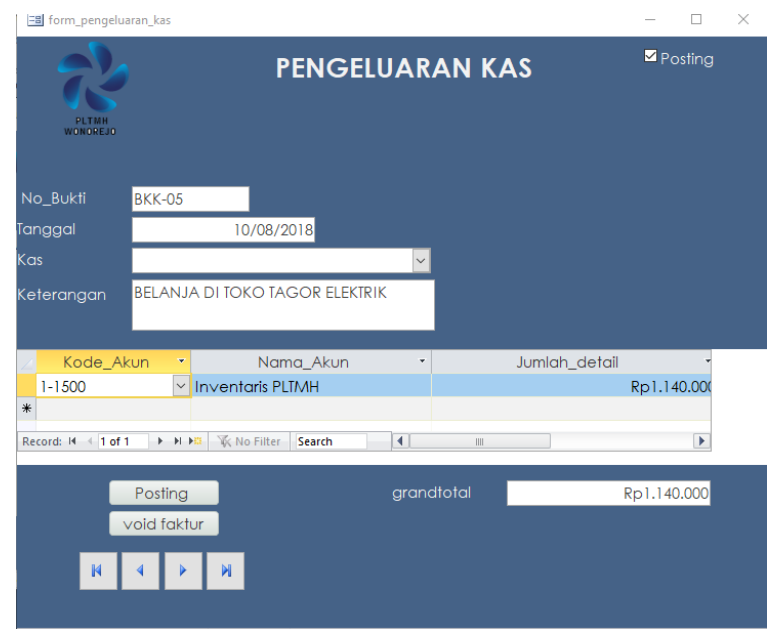

Gambar 8. Faktur Pengeluaran Kas

Tampilan menu laporan, dapat dilihat pada Gambar 9 berikut ini: 


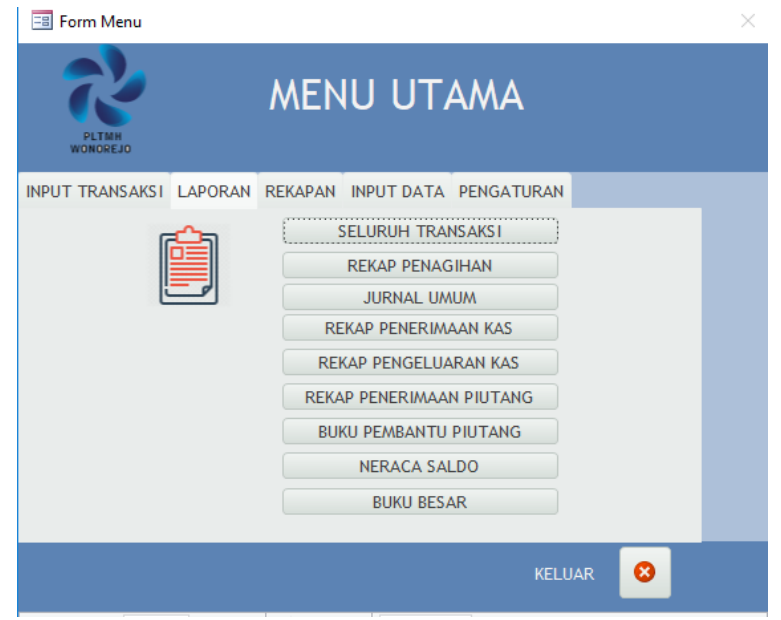

Gambar 9. Tampilan Menu Laporan

\section{Implementasi Sistem}

Metode implementasi yang digunakan adalah metode paralel, dimana PLTMh masih menggunakan prosedur yang selama ini dipakai sambil menggunakan aplikasi yang baru. Pemilihan metode ini untuk menghindari risiko kegagalan sistem baru yang setiap saat bisa terjadi sehingga tidak mengganggu operasional sehari-hari.

\section{Evaluasi dan Pendampingan}

Setelah proses implementasi selesai, perlu selalu berkomunikasi dan memantau penggunaan aplikasi dan peralatan yang telah diberikan untuk melihat permasalahan yang mungkin terjadinya dan mencarikan solusi yang tepat untuk mengatasi permasalahan tersebut. Apabila PLTMh sudah tidak mengalami kendala dalam mengoperasikan sistem yang baru dan dirasa sudah bisa untuk mandiri, maka proses implementasi dan evaluasi telah selesai.

\section{Referensi}

[1] Ikatan Akuntansi Indonesia. 2010. Standar Akuntansi Keuangan, Jakarta.

[2] Madcoms. 2008. Microsoft Access 2007. Yogyakarta: Penerbit Andi dengan MADCOMS.

[3] Mulyadi. 2010. Sistem Akuntansi, Edisi 5. Salemba Empat, Jakarta.

[4] Romney. 2006. Accounting Information Systems. Pearson International

[5] Soemarso SR. 2004. Akuntansi Suatu Pengantar, Salemba Empat. Jakarta.

[6] Yunianto, Bambang. 2011. Prowater sebagai Solusi Pengembangan Pembangkit Listrik Tenaga Mikro Hidro di Perdesaan. Jurnal Mining \& Energi (M\&E). Volume 9 No. 4, Desember 2011 